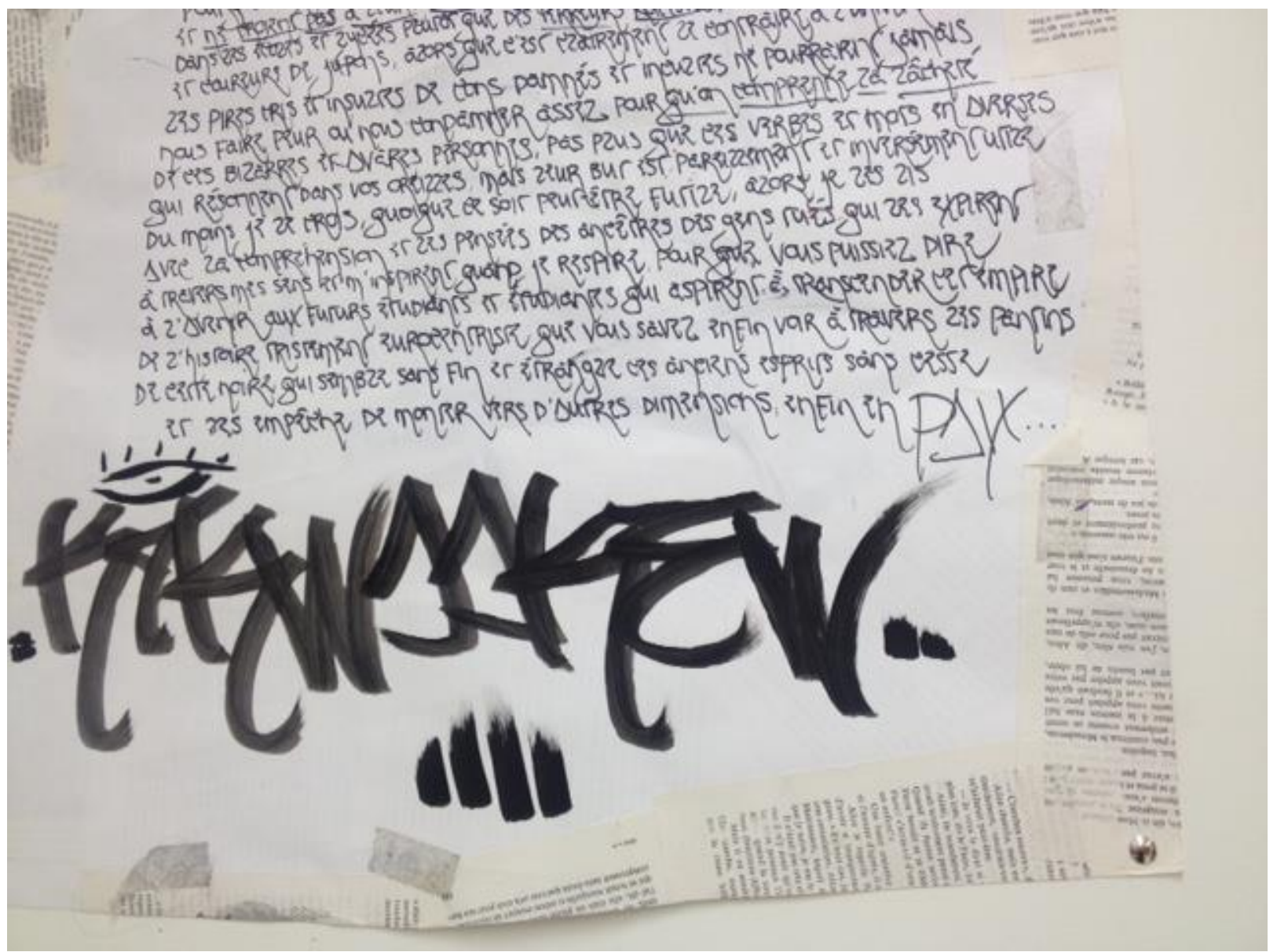

Photo credit: Anton Iorga

\title{
Anticolonial Poetry and Anti-imperial Translation in a Postcolonial Age
}

\author{
Anton Iorga \\ University of Alberta, Canada
}

The poems "Expression, Repression" (a reflection upon one of Bob Boyer's art pieces) and "An Untranslatable History" by Kikwaakew both express the horrors of colonization and Christianization, as well as the hegemonically and patriarchally controlled perception of History (or His Story) which is imposed upon all of us. Within these pieces I also explore the unwritten implications of the words being spoken/written, the satire, the bleakness, the activism at play, as well as many other poetic elements such as rhyme, rhythm, flow, a/symmetry and phonetics which reinforce the anticolonial, educational aspects of these oral literature pieces. More importantly, what is also explored is the genocidal erasing and refashioning of cultural, linguistic and historical memory, and the assimilation even which is unconsciously fostered in using both of these colonial languages (English and French) in the expression of an Indigenous reality which, as much as it seems to be recognized, is nonetheless all-too-often ignored. These pieces were both written not merely as poems but also as short dissertations or even academically uncanny anticolonial conferences, the subversive 
content of which is made to be reinforced by the mnemonic and hypnotic aspect of rhyming. This syncretic form of poetic storytelling shares many similarities with traditional storytelling from a historical perspective, as this modern, poetic storytelling incorporates elements from past oral traditions and recontextualizes them in a current historical/memorial setting. My main concern in the translation of these poems was to stay as true as possible to the spirit of the original work and its gaps, repetitions, rhythm, cadence, syntax and phatic use of language, as well as to the memories/ideologies being conveyed through these devices. In both cases I added a significant amount of lines in French, but I do not believe that I in any way significantly altered the original intent or form of the English poems. In doing so, my goal was rather to further foster the reader's understanding of Aboriginals and their plight, establishing an oral bond between them and the translated poems. As Benjamin suggests in "The Task of the Translator", translation ideally bridges the gap between cultures while expanding their horizons, just as modern, syncretic Indigenous poetic storytelling breathes new life into traditional spiritual practices and beliefs. However, as King warns us about stories, which can be not only healing but also harmful, translation can adversely widen that gap and harm intercultural relationships when improperly harnessed. When properly harnessed, however, translation re-enacts a narrative to launch it in a new language-culture, in the same manner that Indigenous storytelling (both traditional and modern) enacts a performative that not only preserves culture but recreates it anew. Hence my interest in discovering the links between the fashioning of a new world, full of promise, through traditional narrative, and the refashioning of a poetic piece through translation into a new language-culture. Translating the anti-imperialism at work in both of these poems, my intent was to capture the ways in which modern Indigenous poetic storytelling and the bleak, satirical humour with which much of it is tinged, continues to combat colonialism to this day, even in this so-called postcolonial society.

“An Untranslatable History” by Kikwaakew

How could we truly translate a perception of a memory or an event?

Whatever we construe as history remains a skewed perception nonetheless

from rulers who oppressed, we do question it yes,

but do we quest to redress these views with blessed $\&$ dutiful efforts?

we must remember like the nuns and Jesuits

with Native residential terror as education,

we must not forget that to translate into words

the expression of murder, abuse and racism

is to err in ways that cannot properly be expressed or made apparent

to the oppressors \& their grandchildren \& parents, genocide is as scary a concept as is possible to ponder or imagine, so we avoid \& hide subconsciously from it in such a fashion as to demonically justify our ancestors' actions or at least partly forgive their heartless ignorance as rashness so we can walk on and live like this did not actually happen, 
TranscUlturAl, vol. 8.1 (2016), 157-165.

http://ejournals.library.ualberta.ca/index.php/TC

or we talk of such things like "the past is the past",

"let's move on, \& move forward"

but to actually grasp what this means is dubiously rude \& awkward, why do we view conquerors \& explorers as tutor figures

rather than ruthless bigots in the schools of children yet not in universities?

the worst of curses and screams from cursed beings

couldn't possibly scare us enough to muster the hurt of the deeds

of these seedy \& greedy persons, neither could these words I'm speaking

but they serve a purpose it seems, at least I believe or hope so

I read them with the scope of the ghosts that breathe them through me,

so that you may know them \& see through the illusions told

that hold their souls in a noose \& choke them,

$\&$ teach it boldly to students

to seed a new blueprint for more noble beliefs in the future...

"Une Histoire Intraduisible" par Kikwaakew

Comment peut-on traduire une perception en pensée de l'avenir ou du passé, ce que nous pensons être l'Histoire n'est qu'une histoire ressassée

de barbares oppresseurs dont nous n'avons que trop rarement douté

par peur de dérouter de nos louches foutaises,

nous questionnons leurs thèses, oui,

mais essayons nous d'aider ceux qui en souffrent

avec force et effort pour les sortir du gouffre?

Souvenons-nous des nonnes et des prêtres

et frères traîtres et pervers qui prétendaient aider et eduquer les Premières Nations

mais en fait ne faisaient que les abuser et les duper avec des ruses usées,

nous ne devons pas oublier que de traduire avec de simples mots

et expressions pastiches le meurtre, l'abus et le racisme,

n'est parfois rien d'autre qu'une autre forme de répression et d'erreur voilée,

comment traduire une terreur qui ne peut être exprimée

ou rendue evidente dans des textes cités,

une terreur qui ne peut être apparente aux oppresseurs,

à leurs parents et descendants comme leurs petits-enfants,

mais qui l'est trop souvent aux opprimé(e)s,

alors on l'évite et on s'en cache subconsciemment,

parfois trop sciemment ou grossièrement

d'une telle façon qu'on en justifie les actions des démons

que sont une grosse fraction de nos ancêtres,

ou au moins, on pense être plein de compassion

et de compréhension pour eux

This work is licensed under a Creative Commons Attribution 3.0 License

Page 159 
en les croyant simplement ignorants ou un peu douteux, ou douteusement pieux, mais foutaises que ces rêves qui deviennent cauchemars, il n'est jamais trop tard pour changer, qu'il soit tôt ou tard, et des phrases ressassées telles que "le passé est le passé", "avançons vers le futur et laissons les trépassés" sont hautement impolies et inconfortables, et de comprendre ce qu'on tente de masquer n'est souvent que trop âpre, pourquoi croyons-nous que les conquérants qui s'octroient les droits des autres, et ne croient pas à leurs fautes sont des sauveurs et découvreurs de nations dans les écoles et lycées plutôt que des terreurs racistes et facistes et coureurs de jupons, alors que c'est clairement le contraire a l'université? Les pires cris et insultes de cons damnés et incultes ne pourraient jamais nous faire peur ou nous condamner assez pour qu'on comprenne la lâcheté de ces bizarres et avares personnes, pas plus que ces verbes et mots en averses qui résonnent dans vos oreilles mais leur but est pareillement et inversément utile, du moins je le crois, quoi que ce soit peut-être futile, alors je les lis avec la compréhension et les pensées des ancêtres des gens tués qui les expirent à travers mes sens quand je respire, pour que vous puissiez dire à l'avenir aux futurs étudiants et étudiantes qui aspirent à transcender cet empire de l'Histoire eurocentrique que vous savez enfin voir à travers les pantins de cette noire histoire qui semble sans fin, et étrangle ces esprits anciens sans cesse et les empêche de monter vers d'autres dimensions enfin en paix...

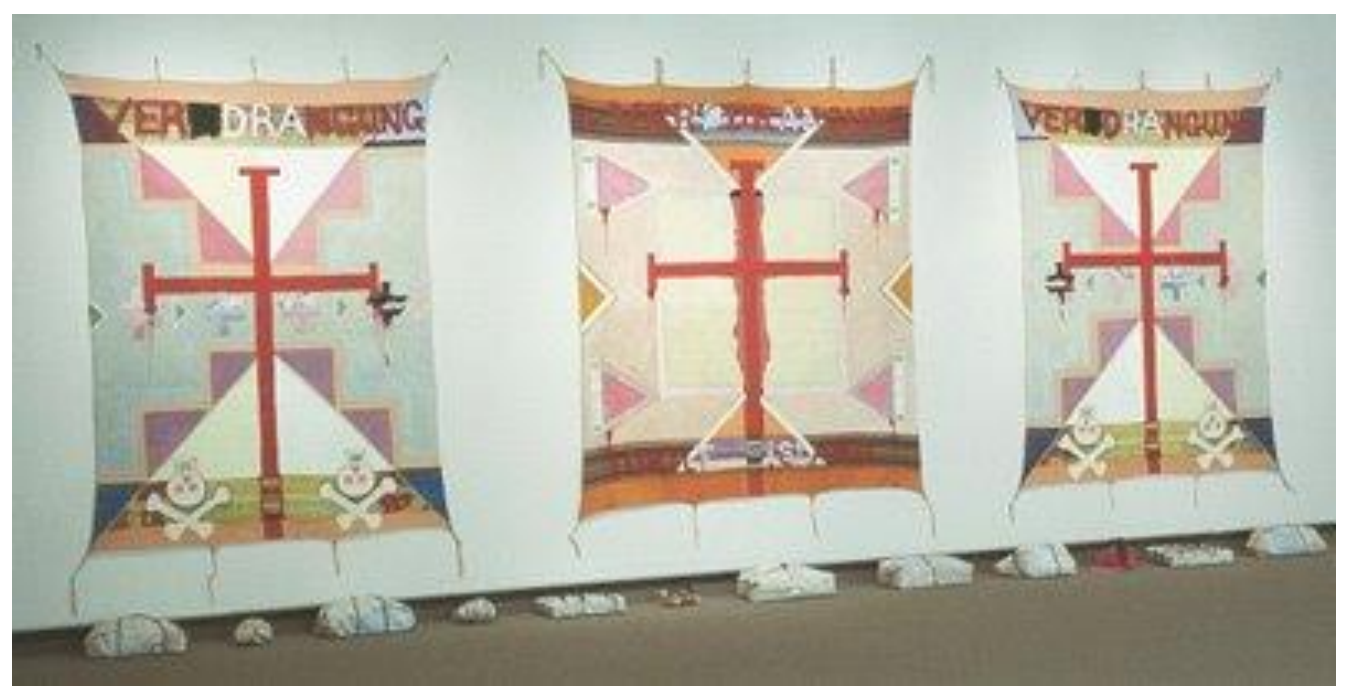

Bob Boyer, Trains-N-Boats-N-Plains: The Nina, the Santa Maria \& a Pinto, 1991.

Road maps, chain, wire, Styrofoam tray, crayon, mixed media and oil over acrylic on blankets, $295 \times 730 \times 50 \mathrm{~cm}$. 
"Expression, Repression” by Kikwaakew

Verdrängung. Turtle Island. Repression. Colonization.

Repressed thoughts of colon-ized Nations

whose so-called pagan faiths were demonized by socio-politically inflated Eurocentric wisdom, perpetuated through slaves of the system who claimed to assist them

by aiding and abetting an 'intrinsic' religious experience

most Natives were wary -and soon became weary- of;

this was really meant to replace plains and lakes by trains, boats and planes

from flakes who came forth from strange places,

with land claims and plans to enslave races

soon-to-be estranged with their Native plains and ancestors' graves,

in the name of some Caucasian deity's decadent representatives,

who spoke of paganism without knowing what it meant linguistically...

In its original Latin sense, Catholic Christians used it profusely back then

to belittle and banter those who professed pantheistic, holistic or animistic preferences...

If we go back in history, or 'His story',

repression is perhaps a large part of the thoughts of underpaid scribes,

forced by knavish tyrants that enforced slavish hierarchies,

to change the line between fact and fiction,

between lax and more accurate reconstructions of both Her \& His stories

which we so desperately lack in our hopelessly conceited and misplaced glory...

We've already seen \& heard THE story of how Christopher Columbus, 'Christ the Colon', paved the way for those who came amongst First Nations

with gifts like infected water, weapons and blankets, things we could easily relate to...

except we ought to have known about the Trojan horse

before blindly molding more minds into 'soldiers of Christ',

without even knowing for whom we were truly prostrated...

Trains-N-Boats-N-Plains: the Nina, the Santa Maria \&o a Pinto, three blanket statements full of lies and deceit

pulled like wool over our sheepish eyes to keep us peaceful, that were meant to be removed and exposed through this piece, replete with symbols completed with geometric precision asymmetrical, with the express intent -the expressed intentionof uncovering unmentionable blunders still covered up because of Verdrängung... Repression in German, with a capital letter for added emphasis on the Word. The same capital letter they tentatively lack to represent when they use the words 'native', 'aboriginal' and 'first nations'... or 'african-american'... 
No worries though, it's simply a subliminal, unintentional by-product of ethnocentric guilt and hatred, transformed into a subversively coercive statement, like taking the blue pill in the Matrix; yet blue bloods still bleed the same red...

the same red as the blood painted dripping from the tainted crosses on those blankets: perhaps this was meant to be a statement of the horrors Yeshua suffered on the Cross for the "greatest of civilizations"... or perhaps it was rather meant sarcastically, to superpose this blasphemy with the pain of colonized Nations, left with the impression that their sufferings -while unintentional and regrettablewere nonetheless in vain compared to Jesus', who saved the entire 'Free World' with his blood and belief system...

So Bob Boyer painted sickly, washed up colours on blankets that became canvases for his pain... the primary colours are decimated like Nature in this painting and installation; well-defined crosses bathe in eerily iridescent light whites and beiges, surrounded by triangles that lead our eyes to see the main piece on this stage: a messy cross, looking like blotting paper, a cross bleeding the lot of Natives who obviously did not discover the Americas, let's face it, since they were simply savage animals in Nature...

Pink, violet and grey-blue, Indian \& Caucasian skin tones stylized in colour-coded geometric shapes, in opposite and complimentary arrangements to enhance the viewer's sense of a strange angst... everything pales as he lets his eyes scale towards the centre, as if most colours had slowly been bled to death, like the Natives that wish they had at least been killed to be laid to rest... yet how could this be in a land left breathless, plagued with infections from settlers who divided it into sections with imaginary lines traced on cartographic projections, based on Western conceptions of ownership and tenancy: mulch and minerals commodified as private properties and residences...

This is what Boyer is representing with his use of European travel fetishes wrapped up in maps, tied up with chains and wires, or even with pink ribbons, to make them seem nicer; a random Styrofoam tray as a bleak reminder of stray litter left behind by colonizing Caucasians made bitter from the inexplicable resistance of First Nations, and their reticence to recognize the validity of treaties' words based on the 'supreme' authority of 'royal' patrons with absurd claims; a crayon to first trace the outlines of the basis for the worst-case scenario in relatively recent history -believe me, this is certainly not ancient: 
TranscUlturAl, vol. 8.1 (2016), 157-165.

http://ejournals.library.ualberta.ca/index.php/TC

the charting and delineation of uncharted, virgin spaces

eventually leading to their grievous desecration,

along with the deportation and assimilation, or perhaps in better cases, of the murder and martyrdom

of a larger part of the races that originally populated them,

the luckiest of which were left to express this inoculated hatred and angst

with mixed media and oil over acrylic on blankets, standing wider and taller than all people on planet Earth, with almost three hundred centimetres in height, seven-thirty in girth, and exactly a half-meter in depth.

Then perhaps Jesus wept.

“Expression, Répression” par Kikwaakew

\section{Verdrängung. Turtle Island. Répression. Colonisation.}

Pensées réprimées de Nations colonisées

Dont les soi-disant fois païennes ont été démonisées

Par une sagesse sociopolitisée enflée et Eurocentralisée

Perpétuée par des esclaves de la société qui prétendaient les assister

En voulant aider et faciliter une expérience religieuse intrinsèque de douteuses sectes

Dont la plupart des Autochtones et corps métissés se sont d'abord méfiés

Et dont ils se sont plus tard lassés

Ceci était en vérité fait pour remplacer les lacs et plaines par des actes et thèmes de cinglés

Venus de contrées et d'endroits étrangers

Avec des concessions de terres et des planifications d'assimilation

Et d'asservissement d'ethnicités qui seraient bientôt séparées de leurs contrées natales

Et des pierres tombales de leurs ancêtres,

Au nom de représentants d'une déité javellisée décadente

Parlant de paganisme aborigène sans en savoir les origines étymologiques latines

Les Catholiques l'utilisaient profusément en ce temps pour ridiculiser et châtier

ceux qui professaient des préférences animistes, panthéistes ou holistes

Si l'on retourne en arrière dans son Histoire

Car l'on ne peut pas dire «sa », quoique le mot soit féminin

La répression des destins est peut-être une grande portion des pensées de scribes sous-payés

Forcés par des tyrans porcins enforçant des castes blasphématoires

à travailler comme des forcenés pour changer l'Histoire

Et tracer la ligne entre fiction et réalité,

Entre controverses et reconstructions de savoir d'à la fois

sa et son Histoire tellement désespérément dus

This work is licensed under a Creative Commons Attribution 3.0 License 
Dans notre gloire méconçue et éperdument décousue...

On a déjà vu et entendu la seule, l'unique histoire de Christophe Colomb

«Le Christ Colon » qui a pavé le sentier pour ceux qui sont venus coloniser

Les Premières Nations avec des dons comme des boissons,

des armes, des couvertes et des cadeaux infectés,

des découvertes auxquelles on pourrait facilement s'adapter...

sauf qu'on aurait dû savoir à propos du cheval de Troie

Avant d'aveuglément forger d'autres mentalités de soldats du Christ

Sans même s'imaginer devant qui on était prostrés en réalité...

Trains-n-boats-n-plains : the Nina, the Santa Maria \& a Pinto

Trois couvertures d'un constat global rempli de menteries et de déceptions

pour aveugler nos yeux de moutons et nous pacifier

Qui étaient destinées à être enlevées et exposées par ces toiles

Remplies de symboles complétés avec une précision géométrique asymétrique

Avec l'intention formelle, intention exprimée,

de mettre à jour de lourdes bourdes de gourdes

qui se sont gourés, fourrés, fourvoyés, à cause de Verdrängung...

«Répression » en Allemand, avec une majuscule, pour mettre l'emphase sur le Mot.

La même majuscule qu'ils tentent subtilement de ne pas représenter

Quand ils chantent les mots « autochtone », « aborigène » et " premières nations »

ou «africain-américain » avec leurs airs enchantés... mais on va les faire déchanter...

Il ne faut surtout pas vous inquiéter, ce n'est qu'un simple malentendu, sous-produit subliminal, non-intentionnel de haine et de culpabilité ethnocentrée

transformé en une déclaration subversive coercitive, comme d'avaler la pilule bleue dans la Matrice,

mais les sang bleus saignent quand même le même sang, vieux...

Le même sang que celui dégoulinant des croix corrompues sur ces couvertes :

Peut-être est-ce voulu comme étant une déclaration des horreurs

que le Christ a souffert sur la Croix pour « la Civilisation Suprême »...

Ou peut-être même est-ce sarcastique, pour superposer ce blasphème

avec la douleur des Nations colonisées, qu'on a laissées avec l'impression

Que leurs souffrances, quoique exécrables et regrettables

Étaient tout de même vaines en comparaison avec celles du Christ

qui a sauvé l'entièreté du «monde libre », le monde entier, avec ses croyances et son sang... pitié

Alors Bob Boyer a peint des couleurs malades et délavées sur des couvertes qui sont devenues des toiles pour sa douleur blafarde...

Les couleurs primaires sont décimées comme la Nature l'est dans cette installation, des énormes croix baignant dans une constellation de beiges et de blancs pâles sinistrement iridescents, entourées par des triangles 
qui mènent nos yeux vers la pièce principale de cette scène :

une croix bâclée, ressemblant à du papier buvard, une croix qui saigne la Foi des Indiens bâtards

qui bien sûr n'auraient jamais pu avoir découvert les Amériques, soyons réalistes, puisqu'ils étaient simplement des animaux sauvages dans une Nature bien triste...

Rose, violet et gris-bleu, couleurs de peaux Indiennes et Caucasiennes

stylisées en formes géométriques codées, arrangées de façon complémentaire et opposée

pour augmenter l'idée du spectateur d'une étrangeté angoissée et hantée...

Tout pâlit tandis qu'il laisse ses yeux dériver vers le centre,

Comme si la plupart des couleurs avaient été tranquillement saignées à blanc

Comme les Premières Nations qui auraient au moins aimé être tuées pour se reposer en paix...

Mais comme serait-ce même une possibilité dans une contrée essoufflée,

Empestée et infectée par des colons qui l'ont divisée en sections

avec des lignes nées de leurs imaginations tracées sur des projections cartographiques

basées sur des conceptions Eurocentristes de location et de possession :

Notre Terre Mère et ses minéraux marchandisée

En résidences et propriétés privées...

Est-ce que vous voyez ce que Boyer a essayé de représenter,

Avec son usage de fétiches européens de voyage

enveloppés dans des cartes, attachés avec des chaines, ou même des rubans roses

Pour qu'on voit la vie en rose ;

Un contenant de styromousse crade comme souvenir maussade

des ordures sales laissées en arrière par des colonisateurs aryens

Rendus âpres par l'inexplicable résistance des Indiens,

et leur réticence à reconnaitre la validité des mots de traités

Basés sur l'autorité « suprême » de conquérants extrêmes aux exigences sans thème...

Un crayon à mine pour délimiter les contours du scénario du pire des cas de l'histoire relativement

récente, croyez-moi, elle n'est certainement pas si ancienne que ça

La cartographie et la délimitation d'espaces vierges inexplorés

menant éventuellement à leur bouleversante profanation

Ainsi qu'à la déportation et l'assimilation, ou peut-être,

Dans de meilleurs cas, à l'assassinat et au martyre

de la plus grande part des ethnies aborigènes qui y habitaient à l'origine

Les plus chanceux étant laissés là pour exprimer cette haine et cette angoisse inoculées

avec des médias mixtes et des peintures sur des toiles et des couvertures,

Plus grandes que tous les humains sur cette planète Terre,

Avec presque trois cents centimètres de hauteur, sept-cent trente de tour de hanche,

Et exactement un demi-mètre de profondeur.

À ce moment, peut-être que Jésus pleure. 